\title{
Understanding the causes, socio-economic and environmental impacts, and management of veld fires in tropical Zimbabwe
}

\author{
George Nyamadzawo ${ }^{1 *}$, Willis Gwenzi ${ }^{2}$, Artwell Kanda ${ }^{1}$, Alfred Kundhlande ${ }^{1}$ and Chipo Masona ${ }^{1}$
}

\begin{abstract}
Veld fires are a common phenomenon in the predominantly savanna ecosystems of Zimbabwe. Until now no studies have investigated the causes, and socio-economic and environmental impacts of veld fires in Zimbabwe. Yet such information is crucial for planning and implementation of fire prevention and control practices. The present study uses multiple sources of information including review of published literature, reports from regulatory agencies, informal interviews and field observations to address the following objectives; (1) to identify the key causes of veld fires in Zimbabwe, (2) to investigate the socio-economic and environmental impacts of veld fires, (3) to highlight management practices for the control of veld fires and (4) to identify research gaps on causes and management of veld fires in Zimbabwe. This review showed that the main causes of veld fires are anthropogenic. The impacts of fires are multifaceted and are a threat to the bio-physical, social and economic environment because of their trail of destruction and they directly impact all sectors of the economy. Impacts range from loss of livelihoods and income, psychosocial impacts associated with fatalities and family bereavement, loss of biodiversity and disturbance of the hydrological balance. It is very difficult, if not impossible, to prevent veld fires because, besides the negative impacts of veld fires, fire also play an important positive role in many Zimbabwean ecosystems. In view of this, fire management should move away from fire fighting to management practices such as early burning that reduces the negative impact, and enhance the positive effects of veld fires.
\end{abstract}

Keywords: Veld fires; Seasonally dry savannas; Biodiversity; Environment; Fire management

\section{Introduction}

Humans have used fire as a vital tool for natural resource management for thousands of years (SCBD 2001). Traditionally, fire has been used as a management tool to control vegetation structure and composition, for hunting and to recycle nutrients locked in live and dead biomass. These uses have continued up to today particularly in savanna ecosystems of southern Africa and northern parts of Australia (Russell-Smith et al. 2003; Bond \& Keeley 2005). However, improper use of fires often lead to veld fires, which are blazes that get out of control, destroying extensive tracts of forests and grasslands and may result in the loss of biodiversity and human life. In the tropics, fires occur regularly and frequently in the under-storey of

\footnotetext{
* Correspondence: gnyama@yahoo.com

${ }^{1}$ Department of Environmental Sciences, Bindura University of Science

Education, P. Bag 1020, Bindura, Zimbabwe

Full list of author information is available at the end of the article
}

savanna woodlands such as the miombo (Trapnell 1959; Kikula 1986; van Wilgen 2009). Africa is considered as the most fire-prone continent in the world (FANRD 2010) and has been referred to as the 'fire continent' primarily because much of Sub-Saharan Africa, once consisted of a vast landscape of tropical and subtropical fire-prone savannas, and fire-influenced woodlands and shrublands that have been shaped by the longest history of human involvement with fire in the world (Bond et al. 2003; Appiah 2007). The dry and warm winters, experienced over Zimbabwe, combined with abundant grass fuels and ready sources of ignition (both lightning and humans) ensure that fires are a regular feature of savanna landscapes (Bond et al. 2003; van Wilgen 2009). The long-term effects of uncontrolled veld fires are a reduction of bio-diversity through destruction of flora and fauna, reduction of soil fertility, an increased erosion rate (WWF 2001) and decreased infiltration, which lead to less water for livestock, irrigation, fish, wildlife and people. 
In Zimbabwe, the current fire management can be traced to the arrival of the white settlers (1890-1950). Regulations and legislation put in place to protect natural resources included the Natural Resources Act (No. 9) of 1941 and The Native Land Husbandry Act of 1951 (Stocking 1978). The Natural Resources Board was formed to implement fire prevention policies in the commercial and communal farming areas, and protected forests and nature reserves. At farm level, farmers were responsible for establishing fire guards before the start of the dry season, which coincides with the fire season. In addition, most commercial farms were fenced to restrict human movement, thereby controlling veld fires associated with hunting and honey harvesting.

The current fire protection system in Zimbabwe was developed in the 1960s and is based on early detection, quick reaction and suppression (Mudekwe 2007). The present system was put in place after realizing that it is difficult to prevent veld fires, but strategies that aim at mitigating the negative effects of wild fires were more sustainable. This structure was maintained for 20 years after independence, till the year 2000, when the land reform programme was initiated.

Prior to the land reform programme commercial farmers occupied about 16 million hectares (ha), resettlement farmers 3.6 million ha, small-scale commercial farmers 1.4 million ha and state farms 0.1 million ha. In 2000, the Government initiated a land reform program to acquire 12.4 million ha of the 16 million ha in large-scale agriculture to create two new categories of farming subsectors, namely A1 and A2 farms. A total of 4.1 million ha model A1 farms (average 5 ha), 3.5 million ha model A2 farms (average, 318 ha per farmer) were established under the land reform program. About 16.4 million ha is now communally owned land, and the rest is state land (Scoones et al. 2010). However, of late there has been a massive increase in the incidences of uncontrolled veld fires which have inflicted substantial damage to agricultural land, national parks, indigenous forests, commercial timber plantations, rangelands and communal grazing areas. The recent increase in fire incidences has been attributed to newly resettled smallholder farmers (EMA 2011; Phiri et al. 2011).

Regardless of the enactment of several Acts that aimed at preventing fires such the Environmental Management Act (CAP 20:27) of 2007, The Parks and Wildlife Act (CAP 20:14) of 1996 and Forest Act (CAP 19:05) of 1996 and the Traditional Leaders Act of 1998, veld fires remain a perennial problem. Studies by Scholes \& Andreae (2000) and a report by Chenje et al. (1998) suggested that burning is the single largest contributor to greenhouse gases during the dry season in Zimbabwe and in the region. Uncontrolled fires are a threat to the bio-physical, social and economic environment because of their trail of destruction and direct impact on all sectors of the economy. Veld fires have destroyed approximately a million ha annually in Zimbabwe in each of the past 4 years. Besides the loss of biodiversity and economic losses, veld fires also reduce the aesthetic value of the land. Thus, there is need for a thorough understanding of the causes, socio-economic, environmental impacts and management of veld fires. Unfortunately, besides institutional reports (e.g., Judge 1975; WWF 2001; Mudekwe 2007; Nkomo \& Sassi 2009; Phiri et al. 2011), there are few scientific studies (e.g., Furley et al. 2008) conducted on fire in Zimbabwe.

In this paper, we used multiple sources of information including review of published literature, reports from regulatory agencies and field observations to address four specific objectives; (1) to identify the key causes of veld fires in Zimbabwe, (2) to investigate the socio-economic and environmental impacts of veld fires, (3) to highlight current fire management practices and (4) to identify key research gaps on causes and management of veld fires in Zimbabwe. We also borrowed from experiences from other tropical savannas of the world particularly South Africa and the northern parts of Australia (e.g., Trollope \& Tainton 1986; Russell-Smith et al. 2003; Bond \& Keeley 2005; van Wilgen 2009) to recommend on sustainable fire management options.

\section{Methology \\ Study area}

Zimbabwe is located in southern Africa between $19^{\circ}$ and $30^{\circ}$ south of the Equator. The country has a total land area of 39 million ha. Annual rainfall ranges from 500-1500 mm, with a rainy season from November to March. The average annual temperature is $18.6^{\circ} \mathrm{C}$. Approximately 15.6 million ha $(40 \%)$ of Zimbabwe is under forests and woodlands (FAO 2010). The savanna woodlands occupy over 95\% of the country's forest cover, comprising five woodland types: Acacia, miombo, mopane, teak (Baikiae plurijuga), and Terminalia-combretaceae. The miombo woodlands, which are composed primarily of Brachystegia species with Julbernadia globiflora, cover approximately $60 \%$ of the forest areas in Zimbabwe. In these woodlands, both grasses and woody plants are characteristic components and this ensures enough fuel for fires especially during the dry winter months (van Wilgen 2009). Exotic forest plantation mainly under Eucalyptus and pines grown on a commercial basis also form part of the forest cover.

\section{Data collection}

The current study draws data from different sources including published scientific literature, unpublished reports from regulatory agencies, research reports, expert knowledge systems, field observations and informal interviews. The sources of data were reviewed to reveal 
the causes and spatial occurrence of fires in Zimbabwe. Analysis of impacts on socio-economic status focused on broad thematic areas such as household livelihoods and food security, loss of assets, loss of lives, and infrastructure and their psychosocial impacts on communities. The impacts on the environment are discussed under three thematic topics; loss of biodiversity, impacts on quality and quantity of water resources and biosphere-atmosphere exchanges of greenhouse gases and their subsequent impacts on climate change. Current fire management practices including presuppression and field control measures were also identified. Based on the review of scientific literature, key knowledge gaps warranting further research were identified.

\section{Results and discussion}

\section{Causes and spatial extent of veld fires}

Our review revealed several anthropogenic causes of veld fires, which can be divided into two categories which are deliberate and accidental fires (WWF 2001). Deliberate fires comprise fires used for hunting, improving grazing, early burning and or back burning to reduce the fuel load and negative impact of wild fires, creation of fire breaks, arson and smoking out bees during harvesting of wild honey (WWF 2001). Other deliberate causes of wild fires also include cooking, waste dumps, and carelessness such as throwing out lit cigarettes, religious and the traditional practice of annual burns to improve grazing (Mudekwe 2007), fires to flush out game, fires to please the rain gods particularly when there is an impending drought and safari hunters who deliberately start or leave campfires unextinguished (Judge 1975). Accidental fires may arise from locomotives along some of the major railway lines such as the Bulawayo-Victoria Falls railway line, which has been reported to cause a number of fires, in addition to fires that are caused by lightning or spontaneous combustion during very hot dry summers (Bond et al. 2003; Mudekwe 2007).

In the smallholder farming areas of Zimbabwe, poor farmers who have limited resources and equipment to clear and prepare the land using mechanical methods frequently use fire for land preparation. These land clearing fires often spread beyond the intended area of burn, and turn into wild fires, thereby significantly contributing to forest fires in recent years. Land use strategies such as ranching use fires to remove invasive species and moribund grasses that are unpalatable to livestock and game to give way to fresh growth. This practice of burning pasturelands is common in Zimbabwe and elsewhere in the tropics (Nepstad et al. 1999; Dube 2005). Of late arson has been one of the major causes of fire in areas where there is resource conflict over tenure or access rights (Applegate et al. 2001). In Zimbabwe, cases of arson have been reported in large-scale forested areas where employees are disgruntled over non-payment of salaries or low salaries. Indiscriminate throwing away of lit cigarette stubs and disposal of hot ash has also been identified as the origin of fires (WWF 2001). Crews of long distance haulage trucks often take recesses and put up fires to prepare food. Often, these fires are not put off before departure, and can spread under wind drift to trigger veld fires. In addition, other road users are also responsible for causing road side fires through burning of road servitudes. Evidently, a report by EMA (2011) showed that $60 \%$ of all fires occur within $500 \mathrm{~m}$ from major roads. Fire has been, and is still used as a hunting tool in Zimbabwe. The hunting season often coincides with the dry season, when fuel load is high and dry, conditions which enhance the initiation and spread of veld fires. Similar studies in tropical Indonesia have identified anthropogenic causes of forest fires as land clearing using fire, fire being used as a weapon in land tenure or land use disputes, accidental or escaped fire, and fires connected with resource extraction (Nepstad et al. 1999; Barber and Schweithelm 2000; Applegate et al. 2001).

Veld fires are normally classified according to where they are burning e.g., surface fires which burn along the ground and crown fires which burn the upper parts of trees (Trollope et al. 1990; WWF 2001). The temperature of burning or intensity can also be used for further classifying fires, as fires can be classified as either cool or hot. Intensity is a measure of the release of heat energy per unit time, per unit length of fire front. Cool fires usually occur early in the dry season (late April to June) when there is still moisture in the grass and leaves, and are typically of low intensity $\left(\sim 2000 \mathrm{~kW} \mathrm{~m} \mathrm{~m}^{-1}\right.$ of energy is released), while late dry season fires (August to September) occur when the grass and trees are very dry, and heat energy of up to $8000 \mathrm{k} \mathrm{Wm}^{-1}$ is released, (Williams et al. 1998). Trollope \& Tainton (1986) classified cool fires as fires with and intensity of $<1000 \mathrm{~kJ} \mathrm{~s}^{-1} \mathrm{~m}^{-1}$, while hot fires have intensity $>2001 \mathrm{~kJ} \mathrm{~s}^{-1} \mathrm{~m}^{-1}$. Hot fires are often made hotter and more destructive by the windy conditions in August, September and October and they are a combination of surface and crown fires (WWF 2001). Hot fires which occur during the driest part of the year are often very destructive; they completely wipe out all ground cover, unlike the cool fires which leave a mosaic of burnt and unburnt patches (van Wilgen 2009).

The Environmental Management Agency (EMA) of Zimbabwe, which is the regulatory authority, mandated to manage the environment in Zimbabwe developed a database of fire occurrences in each province in Zimbabwe. In Zimbabwe, fires often occur between June to November, with most of them occurring between August and October (WWF 2001). The official fire season starts on $1^{\text {st }}$ July and ends on $31^{\text {st }}$ October of every year (EMA 2011).

According to Phiri et al. (2011), Zimbabwe's Fast Track Land Reform Program (FTLRP) which started in 2000 resulted in an upsurge in veld fire incidents due to poor 
land clearing methods by the more than 300000 resettled small holder farmers. The FTLRP has encroached into areas that were not used for agriculture resulting in increased fire incidences. According to EMA (2011) 80\% of the veld fires occurred in A1 and A2 model areas (formerly large scale commercial farming area) suggesting that these veld fires were associated with land clearing for agriculture. Data from EMA (2011) show that in 2009, the country experienced a total of 7409 fire incidences that led to a destruction of 950905 hectares of land (Table 1). The figure increased a total of 9361 fire incidences in 2010 leading to 1.2 million ha being lost. This increasing trend during the period 2009 to 2010 may reflect increased land clearing by newly resettled farmers as the government further implemented the land reform program. However, in 2011, the country witnessed a drop in both fire incidences (6 780) and area affected (714 000 hectares) (EMA 2011). A further drop in fire incidences occurred in 2011 when only 1400 incidences occurred, but these destroyed more than 1 million hectares of land (Table 1). Figure 1 shows the spatial extent of fire incidences in Zimbabwe in 2011. Out of the 10 administrative provinces in Zimbabwe, veld fires were most prevalent in Mashonaland West province (2011). A possible reason that could explain the estimated $85 \%$ drop in fire incidences observed between 2009 and 2012, is the vigorous public media campaign educating people about the impacts of improper use of fire that EMA undertook after realizing the damages and negative impacts of caused by fires. Coupled with regular monitoring of fires incidences and enforcement of the relevant regulations by EMA's field teams throughout the country as evidenced by fines issued, this could have deterred would-be fire offenders. In addition the regulatory authority, EMA, empowered local some local chiefs to fine fire offenders. However, the major concern is that even though the fire incidences are decreasing, the area damaged by fires is still large.

\section{Socio-economic impacts of veld fires Impacts on livelihoods and food security}

Fire outbreaks have resulted in increased loss of agricultural produce, reduced food availability for both humans and animals, reduced growth rate of vegetation (WWF 2001), and loss of equipment. For example, one farmer in
Mashonaland Central province lost several tonnes of maize, a combine harvester and other farm equipment from veld fires in 2011. Several other farmers have also lost their crops both infield and when granaries or storage sheds are destroyed by fires e.g., in Mashonaland West province, a farmer lost US\$338 500 worth of seed maize (The Herald 2011). The overall impact is increased food insecurity among households. In some cases other farmers have lost livestock to veld fires, and there has been complete destruction of rangelands such that livestock will have no grazing. This has resulted in poor beef quality, low selling prices of livestock, low milk production and these all result in reduced incomes for farmers.

\section{Social impacts of fires}

Acute impacts such as trauma are common among victims who would have secured short-term loans to finance their farm operations. One farmer in Mashonaland West Province lost an entire seed maize crop to veld fires after financing the crop using a $\$ 50000.00$ loan from the bank. The farmer did not have insurance against fires. The farmer has not been able to get back into crop production and is still living in debt as the loan has not been paid two years down the line.

At household level, loss of shelter through veld fires has often left families traumatized. People exposed to forest fires may experience grief. Property loss, such as the destruction of a home or damage to personal goods, can be a source of grief. Lacking shelter, these families often sleep in the open with no food supplies and proper water and sanitation facilities and this may result in stress. Feelings of helplessness may arise among people whose lives and property are threatened by veld fires (Machilis 2002). In most African cultures, poor homeless people are often stigmatized, and this can indirectly result in negative social effects and psychosocial wellbeing. For example, loss of livelihoods sources may result in divorces, and complete disintegration of the family unit.

For resource-poor and vulnerable smallholder farmers, loss of assets, housing and crop harvest further exacerbate their already low food and income security, which may usher them deep into a poverty cycle. In addition,

Table 1 Summary statistics of area damaged, number of reported incidences, tickets issued, dockets opened and fines paid and associated economic damages from veld fires in Zimbabwe for the period 2009 to 2012 (Source: EMA 2011)

\begin{tabular}{cccccccc}
\hline Year & $\begin{array}{c}\text { Area burnt } \\
\text { (ha) }\end{array}$ & $\begin{array}{c}\text { Number of reported } \\
\text { incidence }\end{array}$ & $\begin{array}{c}\text { Number of } \\
\text { tickets issued }\end{array}$ & $\begin{array}{c}\text { Number of } \\
\text { dockets opened }\end{array}$ & $\begin{array}{c}\text { Fines } \\
\text { (US\$) }\end{array}$ & $\begin{array}{c}\text { Number of } \\
\text { human fatalities }\end{array}$ & $\begin{array}{c}\text { Estimated economic } \\
\text { damages (\$) }\end{array}$ \\
\hline 2012 & $>1000000$ & 1400 & 345 & 88 & - & 5 & - \\
2011 & 714000 & 6780 & 240 & 78 & 37539 & 5 & 227214 \\
2010 & 1152413 & 9361 & 30 & 49 & 8160 & 25 & 974376 \\
2009 & 950905 & 7409 & - & - & 37539 & 10 & 1984560 \\
\hline
\end{tabular}

ha $=$ hectare, Number of tickets issued = tickets showing penalties to be paid by fire offenders, number of dockets opened = fire cases reported and are being investigated by the police. 


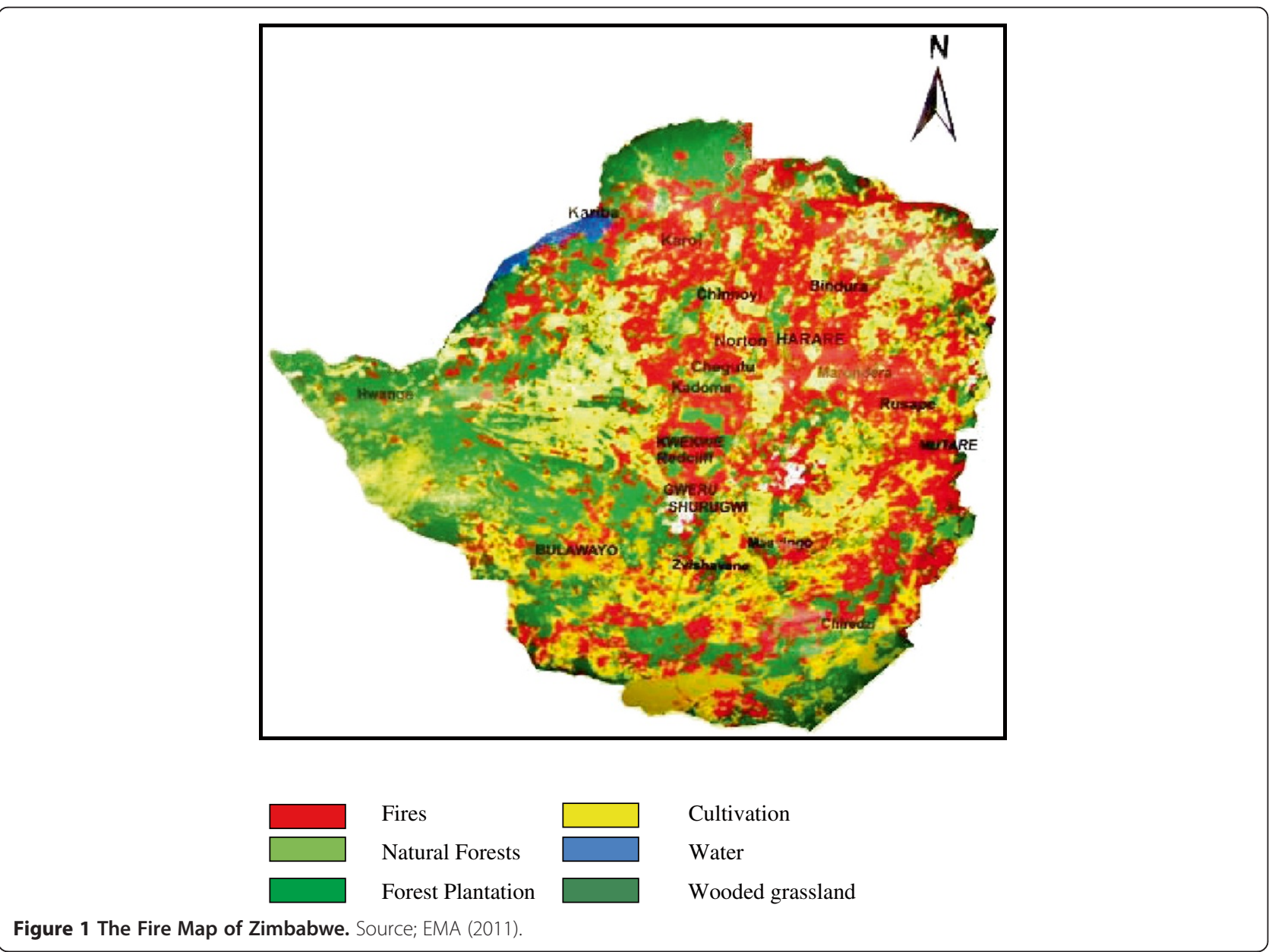

resource-poor farmers would lose their other source of food when the forests are destroyed by veld fires. Most of the rural population depends on both non-forest and forest products derived from forest and woodlands and when they are destroyed by fires the economic cost of these fires is substantial.

Exposure to forest fires impacts psychosocial wellbeing in a variety of ways (Evans \& Kantrowitz 2002; Fowler 2003) ranging from temporary frustration, to temporary or permanent reduction of health-related quality of life (HRQL), to post-traumatic stress disorder (PTSD) feeling jumpy, avoiding reminders of the fire, nightmares, dreams, and disturbing memories (Maida 1989). However, there are no detailed studies that have evaluated both the social and psychosocial impacts of veld fires on people in the affected areas of Zimbabwe and this calls for further research.

\section{Economic impacts of veld fires}

The tropical savanna ecosystem plays an important regulatory role and provides important ecosystem goods and services. Ecosystem functions refer variously to the habitat, biological or system properties or processes of ecosystems. Ecosystem goods (such as food) and services (such as waste assimilation) represent the benefits human populations derive, directly or indirectly, from ecosystem functions (Costanza et al. 1997). Wildfires often result in widespread destruction and damage to a range of these ecosystem services, economic assets and functions (Stephenson et al. 2012). The costs of veld fires on ecosystem services are difficult to quantify in monetary terms because they involve ecological processes and services that are not fully 'captured' and are not traded on formal markets, but that sustain the production of food, fibre, and commerce, as a results they are given little weight in policy decisions. Costanza et al. (1997) divided ecosystems ecosystem services into 17 categories which included; gas regulation, climate regulation, pollination, biological control and nutrient cycling, and the estimated value for the ecosystem services for the tropical biome $\left(1,900 \times 10^{6}\right.$ ha globally) was is estimated to be $\$ 2,007 \mathrm{ha} \mathrm{yr}^{-1}$. However, very few studies have evaluated the impacts of fires on ecosystem services in Zimbabwe, e.g., Nkomo \& Sassi (2009).

At global level an estimated 150 to 250 million ha of the 1.8 billion ha of tropical forests are destroyed by wildfire annually (Appiah 2007) and this represents a 
massive loss in ecosystem services that can sustain mankind. In Manicaland province of Zimbabwe, fires have resulted in the destruction of 1694.3 ha of timber which constitutes the backborne of the Province's economy in 2012. The statistics show that between July and November 2011, 257 forest fires were reported and destroyed 9586 ha of timber constituting 12\% of Zimbabwe's pine population (The Herald 2012). In 2010, 61 huts and 2908 ha of plantations were also destroyed in Manicaland. The timber industry employs an estimated 10000 people directly at its peak in Manicaland province and another 30000 people in the downstream industries. The destruction of timber plantations has dire consequences on the economic status of the province.

In Zimbabwe fires have resulted in serious economic damages to various sectors of the economy (Table 1). However, many of the economic losses are not quantified in monetary terms. In many cases, wildfire caused heavy financial losses in terms of people losing their homes and property. Probably the biggest economic losses from fires are actually felt by the local communities who depend on the forest for services and goods, on recreation, spiritual values, biodiversity and the provision of forest services and ecological functions (such as erosion control, soil formation, nutrient cycling, water supply and regulation, waste treatment and storage of carbon) (SADC 2010). Most of the rural populations rely heavily on resources derived from forest and woodlands e.g., mazhanje (Uapaca kirkiana fruit), thus it can be assumed that the economic cost of these fires is substantial (Nkomo \& Sassi 2009). However, most of the economic losses from fires have not been quantified in monetary terms except for just a few isolated cases.

Smoke and "haze" from forest fires produce some of the most visible impacts to society. People suffer respiratory problems, which put pressure on the already stretched medical facilities in many tropical countries such as Zimbabwe. Respiratory diseases, asthma, skin and eye diseases have been linked to occurrences of wild fires, for examples in Brazil, the number of patients who are admitted into hospital with respiratory related problems doubles during the peak of the burning season (Nepstad et al. 1999). The few documented economic losses are just a tip of the iceberg. The economic impacts of fires are huge, though they are largely unquantified, thus there is need for more studies to evaluate these.

\section{Environmental impacts of veld fires Impact of fires on biodiversity}

Fire serves an important function in maintaining the health of certain ecosystems, but because of misuse of fire, fires are now a threat to biodiversity. Forest fires have many implications for biological diversity as they affect both apparent diversity (observed directly) and hidden diversity (observed by manipulation of the propagule pool in the soil). At the regional and local level, fires lead to change in biomass stocks, and alter plant and animal species' functioning. For example, the smoke from fires can significantly reduce photosynthetic activity (Davies \& Unam 1999).

One of the most important ecological effects of burning is the increased probability of further burning in subsequent years as dead trees topple to the ground, opening up the forest to drying by sunlight, and building up the fuel load with an increase in fire-prone species (van Wilgen 2009). The consequence of repeated burns is detrimental because it causes impoverishment of biodiversity and the extinction of some tree species and the replacement of vast areas of forest with grasslands (WWF 2001). Beringer et al. (2007) reported net biome production of -2.0 tonnes carbon $\mathrm{ha}^{-1}$ year $^{-1}$ in fire prone savannas of Northern Australia. In tropical forests, a single fire can reduce woody plant richness by a third to two-thirds depending on fire severity and can have negative impacts on a diverse array of faunal components (Cochrane 2003). Fires also damage the seed bank, seedlings and saplings and this may hinder recovery of the original species. Fire typically results in some mortality of individual seeds, stems and plants. The magnitude of mortality is dependent upon a multitude of factors including fire intensity, post-fire soil moisture, fruit size, stem size, and species involved (Shackleton 2007). Fire strongly promotes fire-tolerant species, e.g., trees that have thicker, insulating bark (Cochrane 2003; Furley et al. 2008). Although trees in savannas are often thick barked, regeneration of new plants is perhaps the main obstacle for maintaining populations as seedlings and saplings face frequent and severe fire damage in savannas. Given that fires occur several times in a decade, seedlings would need to acquire the ability to re-sprout rapidly (Bond \& Keeley 2005).

Fires can have devastating impacts on forest vertebrates and invertebrates by not only killing them, but also leading to long-term indirect effects such as stress and loss of habitat, territories, shelter and food (WWF 2001). Fires result in the loss of key organisms in forest ecosystems, fruit-eating birds, pollinators, decomposers, amphibians and reptiles resulting in overall decline in these species. For example, the loss of forest food products such as Uapaca kirkiana fruits during the dry season by animals such as monkeys and baboons has resulted in these animals migrating to other areas or invading agricultural crops and destroying young pine plantations in some parts of Zimbabwe. In addition, fires also destroy leaf litter and its associated arthropod community, further reducing food availability for omnivores and carnivores (Kinnaird \& O'Brien 1998).

The impacts of fires are not always negative as fires can also improve the growth of green grass which provides grazing for animals in the dry season, removal of old and normally less palatable dry plant material, the control and reduction of bush encroachment, the stimulation of 
germination of some useful species of grass, and trees and also the limitation of animal parasites (e.g., ticks), (WWF 2001; Nkomo \& Sassi 2009). Surviving seeds may be stimulated to germinate after a fire (Sabiiti \& Wein 1987), and many woody plants in savannas produce multiple coppice shoots to replace those lost or damaged through fire (Shackleton \& Scholes 2000). However, the impact of fires on tropical forest biodiversity, especially in Zimbabwe has received little attention. There are still very few studies on the effects of fires on forest biodiversity in Zimbabwe. An exception is a study by Gandiwa \& Kativu (2009), which investigated the effects of fire frequency on Colophospermum mopane and Combretum apiculatum woodland structure and composition in Gonarezhou National Park. The findings showed that low fire frequency was characterized by a significantly low density of woody plants $(\mathrm{P}<0.001)$, and high mean basal area $(\mathrm{P}<0.001)$, but fire frequency had no significant effect on species diversity (P>0.05) (Gandiwa \& Kativu 2009).

\section{Impacts on catchment and hydrological processes}

Empirical studies on the impacts of fire on catchment and hydrological process are scarce in Zimbabwe. Lacking local field data, we reviewed studies on fire hydrology conducted in South Africa (e.g., Scott 1993) and native woodland ecosystems in Australia, (e.g., Kuczera 1987; Townsend \& Douglas 2000; Cornish \& Vertessy 2001). Similar to Zimbabwe, Australia experiences frequent severe bushfires. However, unlike in Zimbabwe, several studies conducted in Australia have documented the impacts of such fire on catchment and hydrological processes (e.g., Kuczera 1987; Townsend \& Douglas 2000; Cornish \& Vertessy 2001; Shakesby \& Doerr 2006). Figure 2 summarizes the key impacts of fire on catchment and hydrological processes.

After fires, runoff losses are increased as a result of loss of vegetative cover, including leaf litter on the soil surface (Shakesby \& Doerr 2006; Moody et al. 2008). Reduced vegetation cover also reduces canopy interception. Studies have shown that post-fire hydrological behaviour is characterized by low infiltration and enhanced runoff (Scott 1993; Cornish \& Vertessy 2001). In addition, fires may induce water repellency or hydrophobicity, resulting in reduced water infiltration (Doerr et al. 2000). Changes in runoff are more pronounced at larger spatial scales (i.e. hillslope, sub-catchment, catchment and watershed scales), and in Zimbabwe, because fires often occur at larger scales, the impacts observed in studies conducted at subcatchment or catchment scales are more applicable to the Zimbabwean case than those reported at smaller scales.

Considering the connectivity or interactions between surface and groundwater systems, fires may also impact on groundwater resources. However, few studies e.g., Wilson et al. (2010) have investigated the post-fire response of groundwater systems which are more complex than those for surface hydrological processes. For instance, soil texture, the geological formation of the groundwater systems, and the response of vegetation species to fire may interact and influence overall groundwater response of the effects of fire. In the context of Zimbabwe, we make the following inferences; first, on sandy soils with high infiltration and saturated hydraulic conductivity, which are present in most communal areas of Zimbabwe, reduced evapotranspiration associated with fire-induced reduction of vegetation may indeed lead to a rise in groundwater table. Second, on soils with low infiltration and saturated hydraulic conductivity, reduced evapotranspiration may favour the generation of surface runoff, resulting in reduced infiltration and groundwater recharge.

Apart from the impacts on surface and groundwater fluxes, fire also has a profound effect on water quality, particularly surface water resources. For example increased post-fire sediment loads and nutrient concentration (nitrate and phosphates) have been reported following wildfires (e.g., Townsend \& Douglas 2000; Flower 2003; Meixner 2004). Landsberg \& Tiedemann (2000) reported increased sediments loads following wildfires. Interestingly, studies based on prescribed fires revealed relatively negligible effects on water quality, probably due to the small scale at which such studies are conducted (e.g., Richter et al. 1982). However, in Zimbabwe where fires occur at a large scale the impacts of the fires on water quality are likely to be significant.

\section{Impacts on air quality and trace gas emissions}

Although burning is an important management practice, it contributes considerably to the concentrations of greenhouse gases $(\mathrm{GHG})$ such as nitrous oxide $\left(\mathrm{N}_{2} \mathrm{O}\right)$ and carbon dioxide $\left(\mathrm{CO}_{2}\right)$ in the atmosphere. The Intergovernmental Panel on Climate Change (IPCC) attributes $17.3 \%$ of total anthropogenic emissions to biomass burning, making it the second largest source of GHGs from human activities after the burning of fossil fuel. Pyrogenic emissions from Zimbabwe and southern Africa are mostly concentrated in the dry season (July to October) (Scholes \& Andreae 2000). Burning causes significant N and $C$ losses from seasonally dry ecosystems. In Zimbabwe, $\mathrm{N}_{2} \mathrm{O}-\mathrm{N}$ losses from burning were estimated to be 2.36 $\mathrm{Gg} \mathrm{yr}^{-1}$ (Chenje et al. 1998). Scholes \& Andreae (2000) estimated annual emissions of $6.7 \mathrm{Gg}$ for $\mathrm{N}_{2} \mathrm{O}, 7.2 \mathrm{Tg}$ for $\mathrm{CO}_{2}, 0.008 \mathrm{Tg}$ for methane $\left(\mathrm{CH}_{4}\right), 0.265 \mathrm{Tg}$ for carbon monoxide (CO) and $0.019 \mathrm{Tg}$ for NOx from burning in Zimbabwe. The work by Chenje et al. (1998) and Scholes \& Andreae (2000) suggest that burning is the single largest contributor to atmospheric $\mathrm{N}_{2} \mathrm{O}$ and $\mathrm{CO}_{2}$ during the dry season in Zimbabwe and in Southern Africa. 


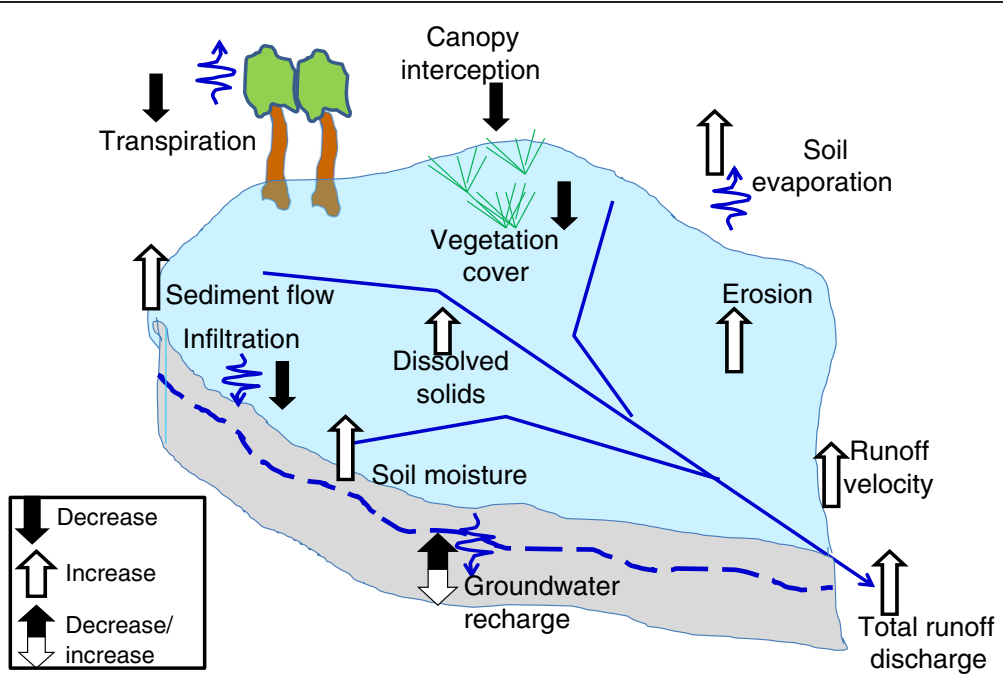

Figure 2 A model showing the impacts of fire on catchment and hydrological processes. Redrawn and modified with permission from Smith et al. (2011).

The resulting air pollution from veld fires may also be a source of public health risks and psychological distress as it alters the natural concentrations of atmospheric gases. For example, ozone, a component of air pollution is associated with negative emotions and aggressive behaviors (Evans \& Kantrowitz 2002). Rotton (1983) reported that bad odors that often accompany air pollution episodes cause evaluative and cognitive deficiencies as well as behavioral disorders. However, beside the estimates of trace gas emissions from burning conducted more than a decade ago by Chenje et al. (1998) and Scholes \& Andreae (2000), presently there is no data on the impacts of burning on atmospheric concentrations of gases and on psychological distress in Zimbabwe.

\section{Fire prevention and control mechanisms Legal and institutional mechanisms to prevent and control veld fires}

The Government of Zimbabwe has put in place several legislative provisions with regards to veld fire management and control. It is a statutory requirement under Statutory Instrument 7 of 2007 (EMA 2007) that any land users, owner or occupier of any land should put in place fire prevention mechanisms. The regulations compel land users, owners and occupiers to have pre-suppression, suppression and post-suppression measures to be in place in order to curb veld fires. According to Statutory Instrument 7 of 2007 as read with Environmental Management Act (CAP 20:27), no person is allowed to light a fire outside residential and commercial premises during the period July 31 to October 31 of each year, which constitutes Zimbabwe's fire season. In cases where one intends to undertake burning outside residential and commercial premises, it is a legal requirement to inform one's neighbours of the intention to burn. The Traditional Leaders Act of 1998 empowers traditional leaders to apprehend and prosecute environmental offenders including those that breach veld fires regulations. Parks and Wildlife Act (CAP 20:14) of 1996 (Parks and Wildlife Act 1996) also have measures that are put in place before the start of the fire season in order to avoid and curb veld fires. The measures include putting in place boundary or standard fireguards that are at least $9 \mathrm{~m}$ wide for external boundaries or fireguards that are at least $4.5 \mathrm{~m}$ wide for internal boundaries. In addition, forest areas should be kept clear of any flammable material and the lighting of fires during the fire season is prohibited. In an attempt to reduce the impact of fires in protected forests, forest fire protection measures are mandatory under the Forest Act (CAP 19:05) of 1996. These fire protection measures include; controlled burning of fireguards and, around selected areas of productive forest; maintenance of fire lines by disking or hand scuffling; and the inclusion of fire protection clauses in the agreements in timber concession, commercial grazing and areas leased for safari operations. Concessionaires are required to remove slash to a distance of two meters from any living stem of a commercial timber species. Three main clauses in the agreements with respect to fire protection are that all fires lit by concessionaires have to be put out after use; workers are responsible for fighting and putting out fires that occur in their areas and workers in concession and leased areas are supposed to help forest managers put out fires anywhere in the forests (Mudekwe 2007). The Forestry Act of 1996, also prohibit smoking in a state or private forestry and that anyone who throws away burning material shall be guilty of an offence and is liable to a fine not exceeding US\$200 or six month in jail or both. According to the Forest Act of 1996, the following are considered as 
fire offences; (1) deliberately starting a fire and leaving it unattended;, (2) lighting or assisting in lighting or adding fuel to a fire which spreads or causes injury and damage to property, (3) deliberately failing to extinguish a fire on one's property, (4) failure to have standard fireguards, and (5) failure to report a fire and failure to stop and assist in putting out a fire. Anyone found guilty of any of these stated offences is liable to a fine not exceeding level 14 (US\$5 000) per hectare or imprisonment for a period not exceeding one year or both. Despite the existence of such an array of regulations, the biggest challenge is the lack of enforcement mechanisms. For example, due to poor enforcements such fines and imprisonments are hardly applied. Consequently, the laws are ineffective and not adhered to. Besides poor enforcement, the fines and penalties imposed on people who start any fires are also very menial and not deterrent. Offenders pay very small amounts in fines which are as little as US\$50, which are considered non-deterrent and too little compared to the damages caused. Moreover, currently, perpetrators are not legally obliged to compensate victims for the damage. This is particularly so, given that identification of the perpetrators is often difficult.

In addition, the legal process to prosecute the perpetrators is very long. According to EMA, the process of prosecution of environmental crimes in the country's courts is taking too long with some cases dating as far back as 2010 receiving judgments only in 2012. For instance, in 2012, a total of 1400 fire offences were committed, but only 345 tickets for fines were issued since the beginning of the fire season (1st of July) to 30 September 2012. Out of these 1400 fire offences, only 88 dockets have been opened at various police stations across the country. Similarly, in 2011 a total of 6780 fire incidents were recorded but only 240 tickets worthy only US\$37 539 were issued. These data evidently demonstrate that the police and court system in Zimbabwe do not consider fire offences seriously like other criminal offences. This is possibly due to lack of manpower and financial resources, and perceptions or attitudes of the authorities responsible.

\section{Preventive methods}

The Environmental Management Agency (EMA) has passed a series of regulations in an attempt to prevent veld fires. For example, Statutory Instrument 7 of 2007, which governs veld fire management in the country compels users, owners and occupiers of given pieces of land to have pre-suppression measures to curb veld fires. Pre-suppression/prevention measures are a series of steps that are put in place before the start of the fire season in order to avoid and curb veld fires. A good fire preventive strategy should aim at minimizing the adverse effects of fire, and promote sustainability of livelihoods, human health and security. These are the social aspects affected by wild fires (van Lierop 2011). Early burning is one such technique which has been used (WWF 2001; Mudekwe 2007). The objective of early burning is to reduce fuel loads and therefore minimize the occurrence of devastating late dry season fires. Early burning creates a patchwork effect of burnt, partially burnt and unburnt areas which leaves substantial amounts of grass and browsing material intact to support wildlife and animal populations during the late dry season. The late hot season fires are checked by the patchwork effect ("firebreaks") created by early burning (WWF 2001). However, early burning is considered essential to complement the fireguard system. In addition, controlled grazing to reduce fuel load is the most promising and effective way to prevent veld fires and this is still practiced by communities adjacent to forested areas and those possessing commercial grazing leases.

\section{Fire suppression and control measures}

Fire suppression and control measures are practices undertaken when there is a fire outbreak in order to reduce environmental damage and loss of property and human life. Under current legislation, it is mandatory for everyone to extinguish all fires on their property regardless of origin of the fire (EMA 2007). In case of a fire outbreak any person within the vicinity of the fire other than the user or the owner of that land shall carefully and properly extinguish the fire. The Act also requires that, once the fire has been suppressed, post-fire suppression measures are undertaken. The post-suppression measures include an investigation and documentation of the cause of fire and the extent of the damage to the environment, property or loss of life within a period of seven days from the day of occurrence of that fire. The responsibility to conduct post-suppression measures falls under the land user, landowner, designated authority, village head, chief, ward councilor or local authority. Upon completion of the investigation, a report should be made to the nearest EMA office and the state police within a period of seven days stating the date of the fire, cause of fire, extent of damage measured in terms of hectares, property and injury or loss of life. While the procedure to be follow is quite clear, they are often ignored in most cases, further emphasizing the lack of enforcement.

Besides EMA and the police, traditional leaders are empowered under the Traditional Leaders Act to apprehend and prosecute environmental law offenders including those that breach veld fires regulations. A study by Christianson et al. (2012) reported that local leadership played a key role in the prevention and control of veld fires, and fines imposed by traditional leaders are legally binding. To this end, the Environmental Management Agency (EMA) has trained a total of 537 traditional leaders in fire management, who are mandated by the law to preside over environmental offences. However, 
this number is still too low to be effective, hence the need to train all leaders, village heads and chiefs in the country to prosecute and preside over fire offences. The local leaders often lack capacity to execute their duties when they are not properly trained to handle fire cases. Thus, it is suggested that enforcement of laws and regulations should be decentralized so that all chiefs can handle such cases in their local areas and that fines should be proportional to the damages caused. The laws should also be amended so that those who start fires are not only fined, but should also pay for the damages to the victims. Instead of fines, alternative forms of punishment such as jail terms should be considered to prevent people from starting veld fires. To expedite the processing of fire crimes, a special court should be established for that purpose.

\section{Recommendation}

Although the legislative framework for the prevention and control of fires already exists, EMA should improve its preparedness to fight veld fires. This preparedness include the need to acquire firefighting equipment and training of their own manpower particularly fire fighters and community fire fighters. It is also important for EMA to have at least one stand-by fire firefighting and emergency plane in each province. Such a plane will be used emergency evacuation and firefighting, where it will be too risky to use ground-based fire gangs. This will not only influence the community readiness to fight fires, but also create employment opportunities for the local communities (Christianson et al. 2012). EMA should also establish fire stations with proper equipment and personnel in fire-prone provinces. In addition, EMA should intensify veld fire awareness campaigns in communities especially in the A1 and A2 farming areas, and other stakeholders (EMA 2011). EMA should make training in fire management and control compulsory for all farmers.

There is also need for incorporating traditional leaders and incorporating indigenous technical knowledge systems in fire management. Training in modern techniques for fire prevention and control should be integrated with indigenous knowledge systems (IKS). IKS should be recognized as a source of adaptable fire management strategies, which can be shared among communities. A case in point is the judicious use of small fire by indigenous Australians in the top northern parts of Australia for cultural purposes, hunting and natural resources management (Russell-Smith et al. 2003). When combined with modern techniques such as remote sensing, IKS may yield effective use, prevention and control of fires. This can be achieved through promotion of community involvement, and education about forest resources and the impacts of fires. In this regard, to enhance adoption, the fire prevention and control methods should be closely linked to rural livelihoods and food security; promotion and encouragement of policies that create and support community managed forests; Management and development of fire use to improve outcomes and reduce the incidence of agricultural fires burning beyond the area of intention; Mandating and equipping natural resources managers, in partnership with local leadership and communities and relevant stakeholders to prepare and implementing integrated fire management plans that promote a balance between fire prevention, response and restoration, and discourage strategies that rely too heavily on fire-fighting as the primary means to deal with forest fires. Communities should also work with other number of organisations who can assist in developing burning programmes and offer training in practical fire management (Phiri et al. 2011). These organisations include organizations such as WWF, the Department of Research and Specialist Services, Department of National Parks and Wildlife Management and universities. Practical fire management should be part of the curriculum in schools, colleges and universities.

Counseling and social welfare organizations can help mitigate psychological distress among people who have suffered injuries and loss due to veld fires by providing counseling services and psycho-social support. For example, Project Recovery in the USA provided emotional support for victims of the Cerro Grande fire in Los Alamos (Machilis 2002). Currently our system has few specialists who can handle such cases. The current land ownership structure is also partly to blame for rising cases of veld fires as $80 \%$ of the fire cases were reported in the A1 and A2 farming areas (EMA 2011). Resettled farmers on A1 and A2 farms do not have title to the land. This creates uncertainty and insecurity as they may be moved off that land at anytime. This is a disincentive, such that farmers will not invest in fire prevention. Thus, farmers should be given title deeds to the land to create a sense of security. Christianson et al. (2012) reported that wildfire mitigation programme was influenced by the communal nature of land and home ownership at both the residential and community levels.

There is also need for an integrated regional effort to fight fires in the Southern Africa Development community (SADC) region. Alternatively a SADC fighting team should be put in place to train fire fighters and also to ensure that when there are veld fires outbreaks, support in the form of equipment and personnel can come in. In summary there is need for a holistic and integrated approach which involves all stakeholder and communities to prevent veld fires. Because of the extensive destruction that is caused by veld fires, everyone should play their role in the preventions of uncontrolled fires (EMA 2012). 


\section{Research gaps}

The underlying causes of increasing fire incidents in Zimbabwe are not very clear, thus there is need for research to establish the root causes of increased fire incidence during the fire season. Details on social, psychosocial and economic impacts of fires are very sketchy, thus there is need for detailed assessments. There is need for the development or adoption of an economic loss assessment framework from other regions to addresses the fundamental economic principles commonly lacking in the current methods for estimating economic losses. There is also need to develop consistent methods for estimating environmental impacts, in the form of ecosystem services and a standardized format for valuing a range of indirect economic and social impacts from veld fire in Zimbabwe.

The impacts of veld fires on ecosystems services and goods have not been well quantified. The impacts of fires on greenhouse gases $\left(\mathrm{CO}_{2}, \mathrm{~N}_{2} \mathrm{O}\right.$ and $\left.\mathrm{CH}_{4}\right)$, climate change, and tropospheric condition e.g. ozone layer are not clear, thus there is need for studies to quantify these effects. There is also need to develop more reliable modeling techniques to predict fire outbreaks as this can enable better preparedness. Although we made some inferences on the impacts of fires on catchment and hydrological processes, our understanding of fire hydrology in Zimbabwe remains poor and warrants further research. Any fire management system should incorporate an effective feedback process involving systematic monitoring, based on timely and accurate mapping of burned areas, combined with monitoring both of fire heterogeneity and effects on biota (Parr \& Andersen 2006). The application of modern technology such as geographical information systems (GIS) and remote sensing can assist greatly in the analysis of fire risks and patterns and impact of fire on biotic and abiotic components of the environment (van Wilgen 2009).

\section{Conclusion}

Veld fires cause serious social, economic and environmental damages. Veld fires lead to loss of social well-being, livelihoods and reduce environmental quality. The sectors of the economy most adversely affected by veld fires are include agriculture, forestry tourism and wildlife. Veld fires in Zimbabwe are caused mainly by human activities. However, our understanding of the impacts of veld fires in Zimbabwe is limited due to limited data and research that has been carried out on the impacts of fires. We conclude that it is very difficult, if not impossible, to prevent wild fires. In view of this, fire management should move away from fire fighting to management practices such as early burning that reduces the negative impact, and enhance their positive effects of veld fires. To achieve this, it is imperative to integrate indigenous knowledge systems and modern techniques such as remote sensing and geoinformatics in the development of strategies for the use, prevention and control of veld fires. This review revealed that there is a critical lack of empirical research on fire in Zimbabwe. To address this information gap, there is urgent need to conduct research on the following thematic areas; mapping the patterns of fire risk using remote sensing and geoinformatics, and quantifying the impacts of fire on livelihoods, food security, public health, hydrology and greenhouse gas emissions at different spatial and temporal scales.

\begin{abstract}
Abbreviations
C: Carbon; $\mathrm{CO}$ : Carbon monoxide; $\mathrm{CO}_{2}$ : Carbon dioxide; EMA: Environmental Management Authority; FANRD: Food Agriculture and Natural Resources

Directorate of the Southern Africa Development Community; FAO: Food and Agricultural Organisation of the FAO; Gg: Gigagrams (109); GHG: Greenhouse gases; GIS: Geographical information systems; IKS: Indegenous Knowledge Systems; IPCC: The Intergovernmental Panel on Climate Change; N: Nitrogen; NOx: Oxides of nitrogen; $\mathrm{N}_{2} \mathrm{O}$ : Nitrous oxide; $\mathrm{N}_{2} \mathrm{O}-\mathrm{N}$ : Nitrogen in the form of Nitrous; SADC: Southern Africa Development Community; SCBD: Secretariat of the Convention on Biological Diversity; WWF: World Wide Fund.
\end{abstract}

\section{Competing interests}

The authors declare that they have no competing interests.

\section{Authors' contributions}

GN, originated the idea, generated the draft manuscript, worked on the general introduction, incorporated all comment from co-authors, formatted the manuscript and revised that manuscript. WG, revised the draft manuscript, worked on the section on the effects of fires on hydrology. Kanda A, revised the draft manuscript and contributed the section on cause of fires in Zimbabwe. Kundhlande A, revised the draft manuscript, and contributed on the legal and institutional mechanisms to prevent and control veld fires, and effects of fires on biodiversity. CM, revised the whole manuscript and contributed on the section on effects of fires on biodiversity. All authors conceptualized the research, analysed data and contributed references. All authors read and approved the final manuscript.

\section{Authors' information}

GN holds an MPhil in Soil Science and MSc in Agriculture, BSC (Hons) in Soil Science and a Diploma in Science Education.

WG holds a PhD in Environmental Systems Engineering, MSc in Water Resources Engineering and Management, and a BSc (Hons) in Soil Science. AK1 holds an MSc and a BSC in Pollution Sciences.

AK2 holds an MSc in Tropical Resource Ecology, BSc in Environmental

Science and a Diploma in Forestry.

CM holds an MSc and a BSC in Environmental Sciences.

\section{Acknowledgements}

We are grateful for the assistance that was given by Environmental Management Authority of Zimbabwe (EMA) that made the compilation of this manuscript possible.

\section{Author details}

${ }^{1}$ Department of Environmental Sciences, Bindura University of Science Education, P. Bag 1020, Bindura, Zimbabwe. ${ }^{2}$ Department of Soil Science and Agricultural Engineering, University of Zimbabwe, MP 167, Mount Pleasant, Harare, Zimbabwe

Received: 17 January 2013 Accepted: 12 June 2013

Published: 25 June 2013

\section{References}

Appiah M (2007) Fire: a necessary evil. In: Heikkilä T, Grönqvist R, Jurvélius M (eds) Wildland fire management handbook. Development Policy Information Unit, Ministry for Foreign Affairs of Finland, Helsinki, pp 238-245, Available from: [http://www.fire.uni-freiburg.de/literature/Fire-Management.htm]

Applegate GBA, Chokkalingam U, Suyanto S (2001) The underlying causes and impacts of fires in South-east Asia. Final Report, Center for International 
Forestry Research, International Centre for Research in Agroforestry. USAID, US Forest Service, Bogor, p 58

Barber CV, Schweithelm J (2000) Trial by fire. Forest fires and forestry policy in Indonesia's era of crisis and reform. World Resources Institute (WRI), Forest Frontiers Initiative, in collaboration with WWF-Indonesia and Telapak Indonesia Foundation. WRI, Washington D.C

Beringer J, Hutley LB, Tapper NJ, Cernusak LA (2007) Savanna fires and their impact on net ecosystem productivity in North Australia. Glob Chang Biol 13:990-1004. doi:10.1111/j.1365-2486.2007.01334.x

Bond WJ, Keeley JE (2005) Fire as a global 'herbivore': the ecology and evolution of flammable ecosystem. Trends Ecol Evol 20(7):387-393

Bond WJ, Midgley GF, Woodward Fl (2003) What controls South African vegetation - climate or fire? S Afr J Bot 69(1):79-91

Chenje D, Sola L, Paleczny D (1998) The state of the Zimbabwe's Environment. Ministry of Mines, Environment and Tourism. Government Printers, Harare, p 509

Christianson A, McGeeb TK, L'Hirondellec L (2012) Community support for wildfire mitigation at Peavine Métis Settlement, Alberta, Canada. Environ Hazards 11(3):177-193. doi:10.1080/17477891.2011.649710

Cochrane MA (2003) Fire science for rainforests. Nature 421:913-919

Cornish PM, Vertessy RA (2001) Forest age-induced changes in ET and water yield in a eucalypt forest. J Hydrology 242:43-63

Costanza R, DArge R, Groot R, Farberk S, Grasso M, Hannon B, Limburg K, Naeem S, O'Neill RV, Paruelo J, Raskin RG, Suttonkk P, den Van Belt M (1997) The value of the world's ecosystem services and natural capital. Nature 387:253-260

Davies SJ, Unam L (1999) Smoke-haze from the 1997 Indonesian forest fires: effects on pollution levels, local climate, atmospheric $\mathrm{CO}_{2}$ concentrations, and tree photosynthesis. For Ecol Manage 124:137-144

Doerr SH, Shakesby RA, Walsh RPD (2000) Soil water repellency: its causes, characteristics and hydro-geomorphological significance. Earth Sci Rev 51:33-65

Dube OP (2005) A Collaborative Effort Towards Developing Capacity for Operational Fire Monitoring and Management Systems in Southern Africa, An electronic publication of the AIACC project. Gaborone, [http:// www.aiaccproject.org./aiacc_studies/aiacc_studies.html]. Accessed 2 November

EMA (2011) Environmental Management Authority (EMA) fire assessment report. 2011. Environmental Management Agency (EMA), Benaby Printing and Publishing, Harare

EMA (2012) Environmental Management Authority (EMA) of Zimbabwe. EMA, Harare, Available from: [http://www.ema.co.zw/index.php/component/ content/article/1-latest-news]. Accessed 12 October 2012

Environmental Management Act (2007) Government Printers, Harare, Chapter 20:27. Act 13/2002, 5/2004 (s. 23), 6/2005 (s. 28). Available from: [http://www.law.co. zw/downloads/statutes/20/Environmental\%20Management\%20Act.pdf]

Evans GW, Kantrowitz E (2002) Socioeconomic status and health: The potential role of environmental risk exposure. Annu Rev Public Health 23:303-331

FANRD (2010) Food, Agriculture and Natural Resources Directorate. SADC regional fire management programme document, Draft proposal, June 2010. SADC, Gaborone, Available from: [http://www.fire.uni-freiburg.de/ GlobalNetworks/Africa/SADC\%20Regional\%20Fire\%20Management\% 20Programme\%20Document-Final-6.pdf]. Accessed 30 August 2012

FAO (2010) Global Forest Resources Assessment main report. FAO, Rome, Available from: [http://www.fao.org/docrep/013/i1757e/i1757e.pdf]. Accessed June 15 2011. ISBN 978-92-5-106654-6

Fowler CT (2003) Human health impacts of forest fires in the Southern United States: a literature review. J Ecol Anthropol 7:39-63

Furley PA, Rees RM, Ryan CM, Saiz G (2008) Savanna burning and the assessment of long-term fire experiments with particular reference to Zimbabwe. Prog Phys Geogr 32(6):611-634. doi:10.1177/0309133308101383

Gandiwa E, Kativu S (2009) Influence of fire frequency on Colophospermum mopane and Combretum apiculatum woodland structure and composition in northern Gonarezhou National Park, Zimbabwe. Koedoe - African Protected Area Conservation and Science 51(1):36-48. doi:10.4102/koedoe. v51i1.685

Judge JG (1975) The Kalahari Sand forests of Rhodesia: Management Report. Forestry Commission of Zimbabwe. Forestry Commission, Bulawayo

Kikula IS (1986) The influence of fire on the composition of miombo woodland of Southwest Tanzania. Oikos 46:317-324

Kinnaird MF, O'Brien TG (1998) Ecological effects of wildfire on lowland rainforest in Sumatra. Conserv Biol 12(5):954-956

Kuczera GA (1987) Prediction of water yield reductions following a bushfire in ash-mixed species eucalypt forest. J Hydrology 94:215-236
Landsberg JD, Tiedemann AR (2000) Fire management. In: Dissmeyer GE (ed) Drinking water from forests and grasslands: A synthesis of the scientific literature. General Technical Report SRS-39. USDA Forest Service, Southern Research Station, Asheville, NC, pp 124-138

Machilis GE (2002) Burning questions: A social science research plan for federal wildland fire management, Report to the National Wildfire Coordinating Group. University of Idaho, Moscow, Idaho

Maida CA, Gordon NS, Steinberg A, Gordon G (1989) Psychosocial impact of disasters: victims of the Baldwin Hills fire. J Trauma Stress 2:37-48

Meixner T (2004) Wildfire impacts on water quality. Southwest Hydrology 3(5):24-25

Moody JA, Martin DA, Haire SL, Kinner DA (2008) Linking runoff response to burn severity after a wildfire. Hydrological Processes 22:2063-2074. doi:10.1002/hyp.6806

Mudekwe J (2007) Management Practices for the Protection of Forest Reserves The Case of Kalahari Sand Teak Forest Reserves in Western Zimbabwe. FAO, Rome, Available from: [http://www.fao.org/docrep/010/ j9533e/J9533E00.htm\#TopOfPage]. Accessed 7 November 2012

Nepstad DC, Moreira AG, Alencar AA (1999) Flames in the rain forest: Origins, impacts and alternatives to Amazonian fires. Pilot Program to Conserve the Brazilian Rain Forest. Brasilia

Nkomo GV, Sassi M (2009) Impact of veld fires on land on smallholder farmers in Cashel Valley in Zimbabwe, Natural Resources and Agricultural Development and Food Security, International Research Network, International working paper series No. 09/02. Harare, pp 1-17

Parks and Wildlife Act Chapter 20:14 (1996) The Parks and Wildlife Act Chapter 20:14. Government Printers, Harare, Available from: [http://www. environmental-auditing.org/portals/0/auditfiles/zweng02ar_sm_wildlife.pdf]. Accessed 20 October 2012

Parr CL, Andersen AN (2006) Patch mosaic burning for biodiversity conservation: a critique of the pyrodiversity paradigm. Conserv Biol 20:1610-1619

Phiri M, Zingwena S, Mahamba SM (2011) Community-based fire management; experiences from the FAO funded project in the provinces of Manicaland and Matebeleland North, Zimbabwe. In: FAO, Integrated fire approach: From global monitoring to natural fire management, Fire management working paper FM/27/E. FAO, Rome, pp 51-60, doi:10.1071/WF03015

Richter DD, Ralston CW, Harms WR (1982) Prescribed fire: effects on water quality and forest nutrient cycling. Science 215(4533):661-663

Rotton J (1983) Affective and cognitive consequences of malodorous pollution. Basic Appl Soc Psychol 4:171-191

Russell-Smith J, Yates C, Edwards A, Allan GE, Cook GD et al (2003) Contemporary fire regimes of northern Australia, 1997-2001: change since Aboriginal occupancy, challenges for sustainable management. Int J Wildland Fire 12:283-297. doi:10.1071/WF03015

Sabiiti EN, Wein WR (1987) Fire and Acacia seeds: a hypothesis of colonisation success. J Ecol 75:937-946

SADC (2010) Sothern Africa Development Community (SADC) Regional Fire Management Programme Draft Document, June 2010. SADC, Gaborone, Available from: [http://www.fire.uni-freiburg.de/GlobalNetworks/Africa/ SADC\%20Regional\%20Fire\%20Management]. Accessed 3 November 2012

SCBD (2001) Secretariat of the Convention on Biological Diversity (SCBD). Impacts of human-caused fires on biodiversity and ecosystem functioning, and their causes in tropical, temperate and boreal forest biomes. SCBD Technical Series no. 5. SCBD, Montreal, p 42

Scholes M, Andreae MO (2000) Biogenic and pyrogenic emissions from Africa and their impact on the global atmosphere. Ambio 29:20-23

Scoones I, Marongwe N, Mavedzenge B, Murimbarimba F, Mahenehene J, Sukume C (2010) Zimbabwe's Land Reform: Myths and Realities. Weaver Press, London and Harare. ISBN 978-1-77922-110-0 and 978-1- 84701-024-7

Scott DF (1993) The hydrological effects of fire in South African mountain catchments. J Hydrology 150:409-432

Shackleton CM (2007) The effects of fire on post-fire seed germination of selected Savanna woody species. Afr J Ecol 45:545-549

Shackleton CM, Scholes RJ (2000) Impact of fire frequency on woody community structure and soil nutrients in the Kruger National Park. Koedoe 43:75-81

Shakesby RA, Doerr SH (2006) Wildfire as hydrological and geomorphological agent. Earth Sci Rev 74:269-307

Smith H, Cawson J, Sheridan G, Lane P (2011) Desktop review - Impact of bushfires on water quality: Summary for public dissemination. Australian Government Department of Sustainability, Environment, Water, Population and Communities, Melbourne 
Stephenson C, Handmer J, Betts R (2012) Estimating the economic, social and environmental impacts of wildfires in Australia, Environmental Hazards. pp 1-19. doi:10.1080/17477891.2012.703490

Stocking MA (1978) Relationship of Agricultural History and Settlement to Severe Soil Erosion in Rhodesia. Zambezia 6(2):129-145

The Herald (2011) Veld fires destroy 5 000ha. The Herald, Harare, [http//www.herald.co. zw/index.php?option=com_content\&view=article\&id=15631:veld-fires-destroy-5000ha\&catid=47:agriculture\&ltemid=139]. Accessed 1 October 2012

The Herald (2012) Veld fires stall indeginisation. The Herald, Harare, [http://www.herald. co.zw/index.php?option=com_content\&view=article\&id=46985:veldfires-stallindigenisation\&catid=47:agriculture\&ltemid=139]. Accessed 23 October 2012

Townsend SA, Douglas MM (2000) The effect of three fire regimes on stream water quality, water yield and export coefficients in a tropical savanna (northern Australia). J Hydrology 229(3-4):118-137

Trapnell CG (1959) Ecological results of woodland burning experiments in Northern Rhodesia. J Ecol 47:129-168

Trollope WSW, Tainton NM (1986) Effect of fire intensity on the grass and bush components of the Eastern Cape Thornveld. J Grassland Soc S Afr 2:27-42

Trollope WSW, Trollope LA, Bosch OJH (1990) Veld and pasture management terminology in southern Africa. J Grassland Soc S Afr 7(1):52-61

Van Lierop P (2011) Four years since Sevilla! Progress and challenges of integrated and community-based fire management, Integrated fire approach: From global monitoring to natural fire management, Fire management working paper FM/27/E. FAO, Rome, pp 43-49

van Wilgen BW (2009) The evolution of fire management practices in savanna protected areas in South Africa. S Afr J Sci 105(9-10):343-349

Williams RJ, Gill AM, Moore PHR (1998) Seasonal changes in fire behaviour in a tropical Savanna in Northern Australia. Int J Wildland Fire 8:227-239

Wilson BL, Valentine JL, Kuehs MJ, Swinburn M, Bleby K (2010) Impact of fire on biodiversity of the Gnangara Groundwater System. Report for the Gnangara Sustainability Strategy and the Department of Environment and Conservation. Department of Environment and Conservation. Government of Western Australia, Perth

WWF (2001) World Wide Fund (WWF). Fire management manual. Wildlife management series, Zimbabwe. WWF, Harare

doi:10.1186/2193-0414-2-2

Cite this article as: Nyamadzawo et al:: Understanding the causes, socioeconomic and environmental impacts, and management of veld fires in tropical Zimbabwe. Fire Science Reviews 2013 2:2.

\section{Submit your manuscript to a SpringerOpen ${ }^{\circ}$ journal and benefit from:}

- Convenient online submission

- Rigorous peer review

- Immediate publication on acceptance

- Open access: articles freely available online

- High visibility within the field

- Retaining the copyright to your article

Submit your next manuscript at $\gg$ springeropen.com 